\title{
Osmanlı Arşiv Belgelerinde 1903 Malazgirt Depremi
}

\section{Manzikert Earthquake in the Ottoman Empire Archive Documents}

\author{
Cihat Tanış ${ }^{\mathrm{a}, *}$ \\ ${ }^{a}$ Dr. Öğr. Üyesi, Ahi Evran Üniversitesi, Fen Edebiyat Fakültesi, Tarih Bölümü, 40100, Kırşehir/Türkiye. \\ ORCID: 0000-0002-2000-731X
}

\section{MAKALE BILGIISI}

\section{Makale Geçmişi:}

Başvuru tarihi: 01 Nisan 2017

Düzeltme tarihi: 14 Eylül 2017

Kabul tarihi: 27 Eylül 2017

Anahtar Kelimeler:

Muş

\section{Malazgirt}

Bulanık

Deprem

Yardimlar

\section{ARTICLE INFO}

\section{Article history:}

Received 01 April 2017

Received in revised form 14 September 2017

Accepted 27 September 2017

\section{Keywords:}

Muş

Manzikert

Bulanık

Earthquake
ÖZ

Doğu Anadolu Bölgesi Türkiye'nin en riskli deprem bölgelerinden birisidir. Bölgede tarih boyunca irili ufaklı birçok deprem yaşanmıştır. 1903 yılında Malazgirt'te yaşanan felakette bu depremlerden birisidir. 6,3 şiddetinde olan bu deprem sonrasında Malazgirt ve çevresinde 2803 kişi hayatını kaybederken binlerce bina hasar görmüştür. Depremin bölgede oluşturduğu yıkımın üzerine Osmanlı Devleti bölgeye imkânları dâhilinde yardım etmeye çalışmıştır. Bu bağlamda ilk etapta çadır, ekmek gibi temel ihtiyaçlar giderilmiştir. Bunlara ilaveten enkaz altında kalanların ivedi şekilde çıkarılabilmesi için bölgeye kazma, kürek ve amele gönderilmiştir. Ayrıca devletin doğrudan yaptığı bu yardımların yanı sıra farklı şehirlerden değişik yollarla yardımlar toplanarak bölge insanına ulaştırılmıştır. Böylelikle felaketzedelerin yaraları sarılmaya çalışılmıştır. Bu çalışmanın amac1, tarih ilminin penceresinden bakarak, 1903 Malazgirt depreminin bölgede sebep olduğu sosyal ve maddi etkiler ile devletin ne ölçüde afete müdahil olduğunu ortaya koymaktır.

\section{A B S T R A C T}

Eastern Anatolia is one of the most risky seismic zones of Turkey. A number of earthquakes with changing intensities occurred in the region throughout the history. The Manzikert Earthquake was one of those seisms. Registering a magnitude of 6,3 according to the data of AFAD, the earthquake caused 2803 direct fatalities. Thousands of homes were devastated as well. In order to pick up the pieces after the devastation caused by the earthquake, the Ottoman State rushed to help the people within the bounds of possibility. At the first stage, the state headed for meeting the basic needs, namely tent and bread. In parallel, pickaxes, shovels and labourers were sent to rescue the people from the wreckage in an expeditious manner. In addition to this direct assistance by the state, donations and grants from different cities were collected and sent to the local people. The earthquake-affected region was rehabilitated in this way. Hence, this study aims to reveal the social and material effects of the 1903 Manzikert earthquake in the related region as well as to what extent the state responded to the incident.

\section{Giriş}

Zelzele, Arapça kökenden gelen sözlükte sarsma anlamını ihtiva eden bir olaydır (Devellioğlu, 2002: 1176). Terim olarak, yerkabuğu içerisinde meydana gelen deformasyonların yarattığı ve jeolojide fay olarak tanımlanan kırılmalar sonucu oluşan yer sarsıntıları olarak tanımlanır. Deprem doğal afetler arasında en kısa süreli gelişen ve büyük yıkımlara neden olan bir doğa olayıdır (Yapıc1, 2015: 15; Kılıç, 1999: 671). Bu nedenle günümüzde gündemden hiç düşmeyen bir konu olma özelliğini göstermektedir. Bunda Türkiye'nin deprem açısından son derece riskli bir coğrafyada yer almasının da etkisi büyüktür.

Türkiye, dünyanın en önemli deprem kuşaklarından biri olan Alp-Himalaya deprem kuşağının içerisindedir. Türkiye'nin üzerinde bulunduğu Anadolu Plakası; kuzeyde Avrasya, güneyde Afrika ve Arap Plakası, doğuda Doğu Anadolu Bloğu ve batıda Ege Bloğu tarafından çevrilmiştir. Bu tektonik konumu nedeniyle Türkiye topraklarının tamamına yakını deprem riski altındadır. Amerika Jeoloji Araştırma Kurumu'nun sunduğu listede; dünyada meydana gelmiş tarihi deprem sayısının yaklaşık \%6'sının Türkiye'de

\footnotetext{
* Sorumlu yazar/Corresponding author.

e-posta: cihattanis@gmail.com
} 
gerçekleştiği görülmektedir (Bikçe, 2015: 1). İkinci yüzyıldan 1950'lere kadar Kuzey Anadolu'da 191, Güney Anadolu'da 135, 11. yüzyıldan 1950'lere kadar Batı Anadolu'da 750, Orta Anadolu'da ise 42 deprem meydana gelmiştir (Özer, 2016: 99). Bu veriler durumun ciddiyetine ortaya koymaktadır. Bu bağlamda tarih boyunca Anadolu'da meydana gelen depremler nedeniyle on binlerce kişi hayatını kaybetmiş ve çok sayıda insan evsiz kalmıştır (Kesik, 2000: 29-31).

Muş, Doğu Anadolu Bölgesinde, sosyal ve kültürel açıdan oldukça öneme sahip tarihi bir şehirdir. Bölge depremsellik açısından Anadolu'nun birçok yeri gibi son derece riskli bir bölge olma özelliğine sahiptir. Bu nedenle incelenmeye değer bir konumdadır. Bölgede aktif fay yoğunluğu fazladır. Özellikle Doğu Anadolu Fayı, Karlıova ile İskenderun Körfezi arasında KD-GB doğrultusunda uzanan yaklaşık 550 km'lik uzunluğa sahiptir. Muş ve civarındaki önemli tektonik unsurların yanı sıra Muş'a yakın olan Bingöl, Bitlis, Erzurum ve Van illeri ve civarında bulunan tektonik unsurlar da bölgenin depremselliğini artırmaktadır. Bu nedenle Muş, Bakanlar Kurulu'nun 18.04.1996 tarih ve 96/8109 sayll kararı ile geçerli kılınan Türkiye Deprem Bölgeleri Haritasında 1. derecede tehlikeli deprem kuşağında yer almaktadır (Işık vd., 2017: 2).

Deprem, birçok bilimsel disiplinin araştırma alanına girmektedir. Bunlardan başlıcası jeoloji ve sismoloji gibi bilim dallarıdır. Diğer taraftan tarih bilimi ise geçmişte yaşanan depremlerin sosyal ve ekonomik etkilerini ortaya çıkarabilmek amacıyla bu alanla ilgilenmektedir. Netice olarak farklı bilim dallarında depremler üzerine çok çeşitli çalışmalar yapılmaktadır (Yazıc1, 2012: 114). Tarih bilimi geçmişte yaşanmış depremlerle ilgili ortaya çıkardığı bilgiler ile depremlerin sosyo-ekonomik etkisini tespit etmeye katkı sağlayacaktır. Günümüz teknolojisinde, depremlerin ne zaman gerçekleşeceği tespit edilemiyorsa da nerede ve hatta hangi şiddette olabileceği hakkında bazı tahminler yürütülmektedir (Muşmal, 2008: 517). İnsanlar, çevresel birçok değişikliğe sebep olabilen bu hadise hakkında çok eski dönemlerden itibaren bilgiler vermişlerdir. Söz konusu bilgiler, günümüzde daha ayrıntılı bir hale dönüşmüş durumdadır. Bu çerçevede 1903 Malazgirt depremi ile ilgili Osmanlı arşivlerinde birçok belge bulmak mümkündür. Bunda Malazgirt depreminin aletsel ilk depremlerden biri olma özelliğine sahip olmasının etkisi büyüktür. Arşiv belgelerinde yapılan araştırmalar sonucunda küçük ölçekli veya hasarsız olmasına bakılmaksızın, bölgede hissedilmiş olan depremler doğrudan hükümete bildirilmiştir. Ayrıca belgelerde depremin gerçekleştiği bölgelerden istenilen yardım talebi, sarsıntının etkileri ve ne zaman meydana geldiği gibi bilgiler de tespit edilebilmiştir.

Depremler doğası gereği olayın meydana geldiği anda olup bitmemektedir. Bunların ortaya çıkardı ğ sonuçlar toplumları ve devletleri uzun süre meşgul etmiştir. Özellikle büyük yıkımlara yol açan bir deprem sonrası bölgenin yeniden imarı ve orada yaşayan insanların yeniden normal hayata dönmeleri uzun zaman alabilmiştir (Kılıç, 1999: 671; Ürekli, 2010: 101). Geçmişte yaşanan doğal afetler sonucunda yaşanan bu sıkıntılar tarih araştırmaları için önemli bir malzemedir. Böylelikle bölgenin tarihini aydınlatmaya katkı sağlanmaya çalışılacaktır. Bu nedenle 1903 Malazgirt depremini çalışma ihtiyacı duyulmuştur.
Ayrıca çalıșmanın seçilmesindeki diğer bir neden de bu tür afetlerin tarihsel açıdan yeterince incelenmemesidir.

Netice olarak bu çalışmanın amacı; jeoloji bilimini ilgilendiren nedenler, magnitüd ${ }^{1}$, fay hattı ve depremle alakalı yapılacak çalışmalar ile ilgili alanlarda bilgi vermek değildir (Üzen, 2014: 78). Aksine konuya tarih ilminin penceresinden bakarak, 1903 Malazgirt depreminin bölgede sebep olduğu sosyal ve ekonomik sonuçlar ile devletin ne ölçüde olaya müdahil olduğu anlatılmaya çalışılmıştır. Bunun için, başta Osmanlı arşiv belgeleri vd. kaynaklar kullanılarak depremde yaşananlar, devletin ve halkın bölgeye yaptığı yardımlar ve yapılan diğer çalışmalar ortaya konulmuştur.

\section{Tarihi Belgelerde Depremin Meydana Gelişi ve Yıkımı}

Malazgirtliler 28 Nisan 1903 tarihinde 6,3 şiddetindeki büyük bir deprem ile sarsılmışlardır. İlk şokun ardından alınan haberlerde birçok insanın hayatını kaybettiği anlaşılmıştır. Bu bağlamda bölgede 2803 kişi hayatını kaybetmiş ve 12000 bina kullanılamaz hale gelmiștir. ${ }^{2}$ Malazgirt'e yakın civar köylerden ise epey bir müddet haber alınamamıştır. Depremin hemen akabinde Bitlis Mutasarrıflığı, askeri birlikler ile yardım ekiplerinin olduğu bir grup ivedi şekilde bölgeye gitmişler ve incelemelerde bulunmuşlardır. Akabinde durum İstanbul'a bildirilmiş ve afetzedelere yardım edilmesi istenmiştir (BOA, Y.H.A.US, 447/14; BOA, Y.H.A.US, 447/18; BOA, BEO, 2056/154199).

Afetin ardından Malazgirt'teki kamu binalarının da içinde bulunduğu hemen hemen bütün yapılar yıkılmıştır. İlk belirlemelere göre 80 asker aileleri ile birlikte enkaz altında kalmıştır. Ancak daha sonra 831 askerin daha hayatını kaybettiği anlaşılmıştır (BOA, Y.MTV, 243/00041). Deprem Ahlat'ta da oldukça şiddetli hissedilmiş ve burada 35 hane yıkılmış, 2 kişi ölmüş ve 4 kişi de yaralanmıştır (BOA, BEO, $2055 / 154104)$. Felaketin yanı sıra depremzedeler her an yeni bir sarsıntı yaşanabileceği ihtimaline karşı soğukta sabaha kadar beklemek zorunda kalmışlardır. Kışlalardaki askerler, silahlar ve mühimmatta olası yeni deprem ihtimaline karşı dışarı çıkarılmıştır (BOA, HR.TH., 287/115). Anlaşılacağı üzere afetzedeler bir yandan felaketin yaralarını sarmaya çalışırken diğer yandan soğukla mücadele etmişlerdir. Depremin ardından bölgeye yağmur yağmaya başlamıştır. $\mathrm{Bu}$ nedenle enkaz altındaki yakınlarına yardım etmeye çalışan insanlar bir yandan da yağmur ve çamur ile mücadele etmişlerdir. Ayrıca depremzedeler soğuğun etkisini azaltmak için ateş yakıp kendi imkânlarıyla ısınmaya çalışmışlardır.

Depremden sonraki birkaç gün içinde, birçok artçı sarsıntı hissedilmiştir. Depremde en çok hasara uğrayan yerler, Malazgirt ve Bulanık'tır. Bir kaç yapı dışında diğerleri ağır hasar görmüștür. Depremin ilk şoku atlatıldıktan sonra felaketin ne boyutta olduğu daha da iyi anlaşılmış ve bölgede birçok evin kullanılamaz hale geldiği görülmüştür ( $B O A$, Y.MTV, 243/00041). Buna ilaveten başta Malazgirt olmak üzere bölgedeki birçok devlet kurumu, okul cami gibi yapılarda ciddi zarar görmüştür. Ayrıca depremin merkez üssü Malazgirt olmasına rağmen sarsıntılar çevre vilayet ve kazalarda da şiddetli bir şekilde hissedilmiştir. 


\section{Felaketten Sonra Yapılan Yardımlar}

Depremin hemen ardından Bitlis Vilayetine gönderilen telgrafta enkaz altında kalanların ivedi şekilde kurtarılması ayrıca iskân ve iaşe gibi ihtiyaçların da bir an evvel yerine getirilmesi emredilmiştir (BOA, BEO, 2055/154094). Bu bağlamda yerel idareciler depremzedelere yardım için hükümetten bazı isteklerde bulunmuşlardır (BOA, İ.HUS, 105/1). Osmanlı Devleti ilk etapta afetten etkilenen ahaliye yardım için gerekli ihtiyaçların mahalli mal sandığından sağlanması talimatını vermiştir (BOA, İ.HUS, 105/11). Böylelikle ilk yardımların hızlı bir şekilde bölge insanına ulaştırılması hedeflenmiştir. Özellikle havaların soğuk olmasının da etkisiyle Dördüncü Orduya bir an evvel bölgeye çadır göndermesi emredilmiştir. Bunun üzerine hızlı bir şekilde çadırların bölgeye gönderilmesine başlanmıştır. Benzer şekilde sağ kalanlar için iaşenin çevre vilayetlerden gönderilmesine karar verilmiştir (BOA, İ.HUS, 105/11). Hükümet, 29 Nisan günü Van ve Erzurum Vilayetlerine gönderdiği telgrafla iaşe ve çadır gönderimlerinde daha hızlı davranılması gerektiği uyarısında bulunmuştur (BOA, BEO, 2056/154199). Yardımlar bölgeye ulaştırılırken bir yandan da tetkikatlar yapılarak neye ihtiyaç olduğu doğru bir şekilde tespit edilmeye çalışmıştır. Bu bağlamda yapılan ilk tetkikat sonucunda 150 çadıra acilen ihtiyaç olduğu anlaşılmıştır. Ayrıca enkaz altında kalanların çıkarılması için de bölgeye ilk partide 100 amele gönderilmesi kararlaştırılmıştır. Bunlara ilaveten hafriyat için kazma, kürek gibi aletlerinde gönderilmesi istenmiştir (BOA, BEO, 2058/154316).

Depremin artçı sarsıntıları birkaç gün daha devam etmiştir (BOA, BEO, 2068/155080). Erzurum 29 Nisan günü saat 7.30 civarlarında hafif surette 3 defa sarsılmıştır (BOA, BEO, 2055/154104). Bu sarsintılar ister istemez bölge halkının tetikte ve huzursuz beklemesine neden olmuştur. Hükümetin emirleri doğrultusunda çadırların ve iaşelerin bir kısmı bölgeye ulaştırılmıştır. Yine ilk incelemeler doğrultusunda 2166 kişinin açıkta kaldığı bunların da ivedi şekilde çadıra ihtiyaç duyduğu belirtilmiştir. Buna ilaveten yaralıların tedavisi için gerekli şeylerin yapılması ve vefat edenlerin defin işlemlerinin halledilmesi emredilmiştir (BOA, BEO, 2058/154323). Van'dan 100 çadır daha bölgeye ulaştırılmıştır. Yerel yöneticiler bir yandan enkaz altında canlı kalan varsa onları kurtarmaya çalışırken diğer yandan vefat edenler defin edilmeye başlanmıştır (BOA, BEO, 2059/154384). Hükümet felaketzedelere daha fazla yardımda bulunabilmek amacıyla bazı vilayetlerde yardım kampanyası başlatmıştır (BOA, BEO, 2062/154579).

Bitlis Vilayeti yöneticileri aldıkları emre binaen devlet tarafından yapılacak yardımların miktarının belirlenebilmesi için depremin zararlarının tespitini içeren geniş çaplı bir tetkikat yapılmasını istemiştir (BOA, BEO, 2068/155080; BOA, BEO, 2161/16206). Raporların gönderilmesinin hemen ardından ise zarar gören binaların tamir edilmesi için Bitlis Vilayetine 129.500 kuruş verilmiştir (BOA, BEO, 2135/160061; BOA, BEO, 2155/161600). Yine bu bağlamda yıkılan evlerin yerine yeni barakaların yapılması, ahırların tekrardan inşası, telef olan çift hayvanlarının yerine yenisinin gönderilmesi gerektiği belirtilmiştir (BOA, BEO, 2063/154699). Böylelikle bölgenin yeniden imarının sağlanması amaçlanmıştır. Özellikle Malazgirt hükümet binası ağır hasar almıştır. Bu nedenle hükümet konağının tamiri için acele davranılması istenmiştir (BOA, BEO,
2200/164960; BOA, İ.DH., 1412/23). Bulanık telgrafnamesi de sarsıntılardan dolayı hasar almıştır. Burasının da bir an evvel tamir edilmesi planlanmıştır (BOA, DH.MKT, 737/73). II. Abdülhamid döneminin doğudaki önemli simgesi olan Hamidiye Alayları da bu afetten etkilenerek bazı mensupları hayatını kaybetmiş veya yaralanmıştır. Devlet bu durumda olanlara da aynı şekilde yardımda bulunulması talimatını vererek bu kişilerinde yaralarını sarmaya çalışmıştır (BOA, BEO, 2080/155931; BOA, BEO, 2196/157159).

Hükümet deprem sırasında memleketlerinde olmayan işleri için başka şehirlere giden vatandaşlarını düşünmüştür. $\mathrm{Bu}$ bağlamda örnek olarak; özel işleri için İstanbul'da bulunan Şeyh Ömer ve arkadaşları olan Mehmet ile Ali'nin memleketlerindeki depremden etkilenen yakınlarının yanına bir an evvel gitmeleri için onlara kolaylık sağlanarak idare-i mahsusa vapurları ile ücretsiz olarak memleketlerine gitmelerine izin verilmiştir (BOA, DH.MKT, 714/20). Devletin bölge halkına yaptığı en büyük yardımlardan birisi de depremden etkilenen Malazgirt ve Bulanık halkının 1903 senesi öşür vergisinden muaf tutulması olmuştur. Böylelikle ekonomik olarak zor durumda olan bölge halkının rahatlatılması amaçlanmıştır (BOA, ŞD, 1890/25).

Depremzedelere yardım yalnızca hükümet tarafından yardım yapılmamış aynı zamanda dış yardımlarda yapılmıştır. $\mathrm{Bu}$ bağlamda Avrupa ülkelerinin konsolosları tarafından çeşitli yardımlar yapılmıştır. Ancak bu yardım teşebbüsleri masumane olmaktan uzak Osmanlı Devleti'nin içişlerine müdahale niteliğindedir. Özellikle İngiliz konsolosun bölgede yaptığı faaliyetler oldukça önemlidir. Sarsıntının ardından bölgeye giden konsolos mahalli idarecilerle hiçbir temas kurmadan doğrudan halka yardım ulaştırmaya çalışmıştır. Osmanlı hükümeti bu hareketin ardından yerel idarecilere konsolosların izin almadan halkla doğrudan temasa geçmemesi, yapacakları yardımları da yerel idareciler aracılığıyla yapmaları gerektiğini bilhassa vurgulamıştır (BOA, İ.HUS, 107/116; BOA, DH.TMIK.M., 153/41).

\section{Sonuç}

Malazgirt'in tarihinde yaşadı $\breve{g}_{1}$ en yıkıcı depremlerden birisi olan 1903 depremi şiddeti ve etkileri göz önüne alındığında bölgeye ne kadar büyük bir zarar verdiği bu araştırmayla daha iyi anlaşılmıştır. 28 Nisan 1903 tarihinde meydana gelen depremde 2803 kişi hayatını kaybetmiştir. Ayrıca sarsıntıların şiddetiyle Malazgirt ve çevresindeki binaların büyük bir çoğunluğu kullanılamaz hale gelmiştir. Malazgirt ve çevresinde görülen depremden sonra muhtaç ve yoksul bir durumda olan insanlara yardım elinin hemen uzatılması ve çekilen sıkıntıların azaltılması gerekiyordu. Özellikle zor durumda kalmış insanların en aciz anlarında devletin varlığıyla kendisini insanlara hissettirmesi ve onların yanında olduğunu göstermesi lazımdı. Osmanlı hükümeti bu amaçla ilk etapta bölgeye çadır, ekmek vb. yiyecek ve yaralılara bez vermiştir. Bunun yanı sıra enkaz altındakileri kurtarma çalışmaları ve vefat edenlerin defin işlemleri mümkün olduğunca hızlı bir şekilde yürütülmeye çalışılmıştır. Hükümet ayrıca depremden zarar gören bölge halkının ekonomik sıkıntılarının giderilmesine de önem vermiştir. Depremde hayvanları telef olan köylülere yeni çift hayvanı verilmesi düşünülmüş ve yıkılan ahırların yerine de 
yenilerinin yapılması için para yardımı yapılmıştır. Görüldüğü üzere Malazgirt depreminde büyük acılar

yaşayan felaketzedelerin mağduriyetlerinin giderilmesi için hükümet imkânlarını seferber etmiştir.

Sonuç olarak bu çalışmada, 1903 depreminin incelenmesi neticesinde Malazgirt ve çevresindeki yapıların ve insanların afetten ne şekilde etkilendiği, depremin bölgeye sosyal ve ekonomik etkisi hakkında bilgiler verilmiştir. Ayrıca hükümetin ve yerel yöneticilerin ihtiyaçları ve afetler karşısındaki davranışları hakkında bazı tespitler yapılmaya çalışılmıştır.

\section{Notlar}

1 Magnitüd; yer kabuğunun bir deprem esnasında boşalttı̆̆ enerjinin çeşitli teknolojik aletlerle ölçülmesine denir.

${ }^{2}$ Depremin kaç şiddetinde ve Nisan'ın 28 veya 29'unda mı olduğu hakkında birçok kaynakta farklı bilgiler mevcuttur. AFAD'ın verilerine göre 28 Nisan'da 6,3 şiddetinde olmuş ve 2803 kişi hayatını kaybetmiş iken KOERI'nin verilerinde 29 Nisan'da 6,7 şiddetinde olmuş ve 600 kişi hayatını kaybetmiştir. Murat Bikçe, "A database for fatalities and damages due to the earthquakes in Turkey (1900-2014)", Natural Hazard, Vol. 83, No 3, September 2016, s. 1374; Murat Bikçe, "Türkiye'de Hasara ve Can Kaybına Neden Olan Depremler Listesi (1900-2014), 3. Türkiye Deprem Mühendisliği ve Sismoloji Konferans1, 14-16 Ekim 2015, İzmir,

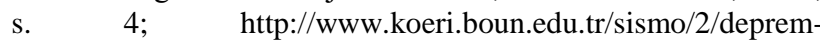
bilgileri/buyuk-depremler._Osmanlı Arşiv vesikalarında da görebildiğimiz kadarıyla $2 \overline{8}$ Nisan üzerinde durulmaktadır. $B O A$, BEO, 002055/154094. Ayrica arşiv belgelerinde depremde hayatını kaybedenlerin sayısı kesin olarak saptanamamakla birlikte KOERI'nin verilerinin çok üstünde olduğu anlaşılmıştır. BOA, Y.MTV, 243/00041. Nitekim 1999 Gölcük Depremi gibi çok yakın bir tarihteki deprem hakkında bile farklı bilgiler varken 1903 yılında olmuş bir deprem hakkında bilgi kirliliğinin olması son derece normaldir. Ayrıca 1903 Malazgirt Depreminin aletsel dönemdeki ilk depremlerden bir tanesini olmasının bunda etkisi büyüktür.

\section{Kaynakça}

Bikçe, M. (2015). Türkiye'de Hasara ve Can Kaybına Neden Olan Deprem Listesi (1900-2014). Türkiye Deprem Mühendisliği ve Sismoloji Konferansi, İzmir.

Bikçe, M. (2016). A database for fatalities and damages due to the earthquakes in Turkey (1900-2014). Natural Hazards, 83(3), 1359-1418.

BOA, BEO, 2055/154104; 2055/154094; 2056/154199; 2058/154316; 2068/155080; 2058/154323; 2059/154384; 2062/154579; 2063/154699; 2068/155080; 243/00041; 2161/16206; 2135/160061; 2155/161600; 2200/164960; 2080/155931; 2196/157159.

BOA, DH.MKT, 737/73; 714/20.

BOA, DH.TMIK.M, 153/41.

BOA, HR.TH, 287/115.

BOA, İ.DH, 1412/23.

BOA, İ.HUS, İ.HUS, 105/1; İ.HUS, 105/11; 107/116.

$B O A$, ŞD, $1890 / 25$.

BOA, Y.H.A.US, 447/14; 447/18.

\section{BOA, Y.MTV, 243/00041.}

Devellioğlu, F. (2002). Osmanlıca-Türkçe Ansiklopedik Lûgat. Ankara:.Aydın Kitabevi.

Işık, E., Aydın, M. C., Bakış, A., \& Özlük, M. H. (2012). Bitlis ve Civarındaki Faylar ve Bölgenin Depremselliği, Bitlis Eren Üniversitesi Fen Bilimleri Dergisi, 1(2), 153169.

Işık, E., Bozkurt, N., \& Taşkın, V. (2017). Muş İli Yap1 Stoğunun Kanada Sismik Tarama Yöntemi ile İncelenmesi ve Bölgenin Depremselliği. Süleyman Demirel Üniversitesi Fen Bilimleri Enstitüsü Dergisi, 21(2), 421-429.

JMO (2017). Türkiye'nin Diri Fay Hattı Haritası. (Erişim: 01.05.2017), http://www.jmo.org.tr/resimler/ekler/ aac58e46db1fcb2_ek.jpg?tipi $=2 \&$ turu $=H \&$ sube $=0$

Kesik, M. (2000). XII. Yüzyılın İlk Yarısında Anadolu'da Meydana Gelen Doğal Afetler ve Depremler, Tarih Boyunca Anadolu'da Doğal Afetler ve Deprem Semineri, İstanbul Üniversitesi Edebiyat Fakültesi Tarih Araştırma Merkezi, s. 29-40.

Kılıç, O. (1999). Mühimme Defterlerine Göre XVI. Yüzyılın İkinci Yarısında Osmanlı Devleti'nde Meydana Gelen Depremler. Osmanl, 5, 671-677.

Muşmal, H. (2008). Konya Eyaleti Ilgın Kazası'nda Yaşanan 1866 Depremi Üzerine Bir İnceleme. Selçuk Üniversitesi Sosyal Bilimler Enstitüsü Dergisi, (20), 517-527.

Özer, S. (2016). 1938 Yı1ı Kırşehir Depremi. Osmanlı Mirası Araştırmaları Dergisi, 3(5), 99-115.

Sezer, C. (2014). 1914 Isparta-Burdur Depreminde Hilâl-i Ahmer Cemiyeti'nin Yapmış Olduğu Yardımlar. Süleyman Demirel Üniversitesi Sosyal Bilimler Enstitüsü Dergisi, 19(1), 17-34.

Ürekli, F. (2010). Osmanlı Döneminde İstanbul'da Meydana Gelen Afetlere İlişkin Literatür. TALID, 8(16), 101-130.

Üzen, İ. (2014). 1942 ve 1943 Erbaa Depremleri. Karadeniz Araştırmalarl, 40, 77-93.

Yapıc1, H. (2015). Tarih Boyunca Erzurum'da Meydana Gelen Zelzeleler. Mavi Atlas, (5), 14-20.

Yazıc1, M. (2012). 1851 Meğri Depremi. Muğla Üniversitesi Sosyal Bilimler Enstitüsü Dergisi, 28, 114-129. 


\section{Ekler}

Ek-1: Türkiye'nin Diri Fay Hattı Haritası.

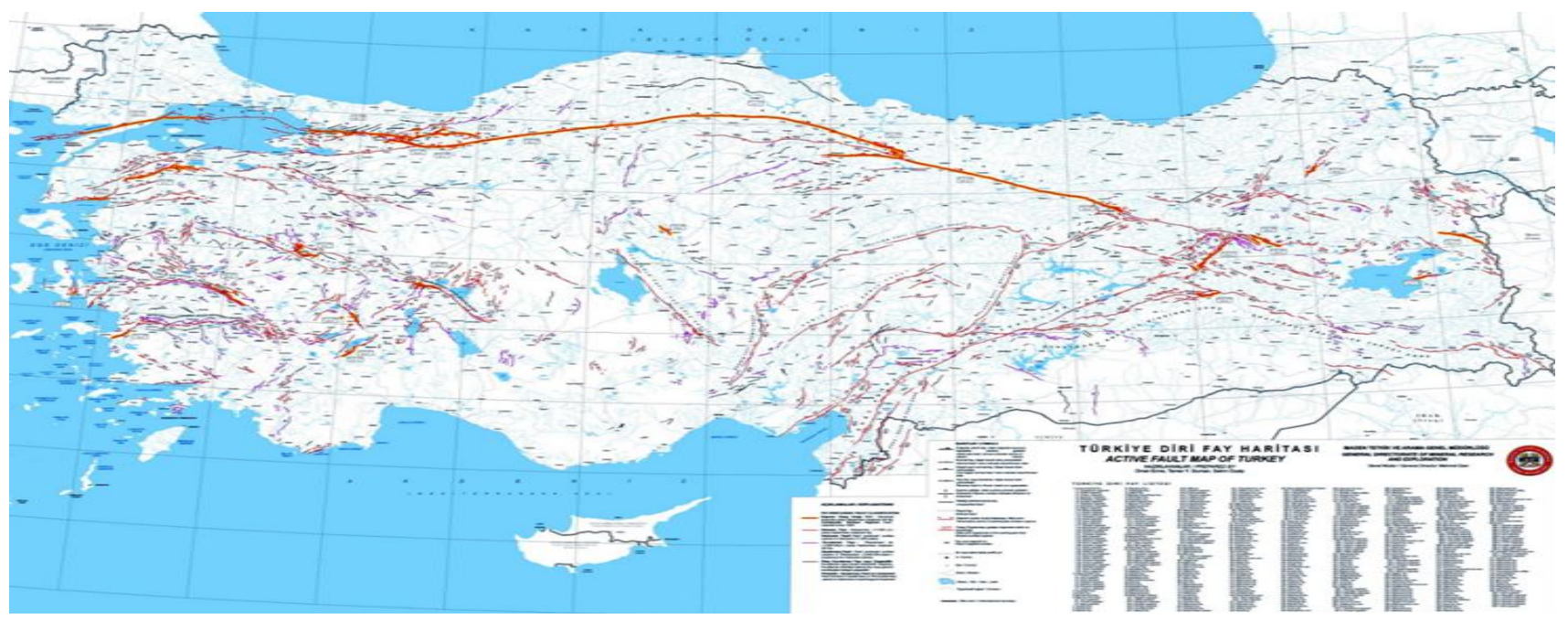

Kaynak: (JMO, 2017).

Ek-2: Muş ve civarının tektonik yapısını gösteren harita.

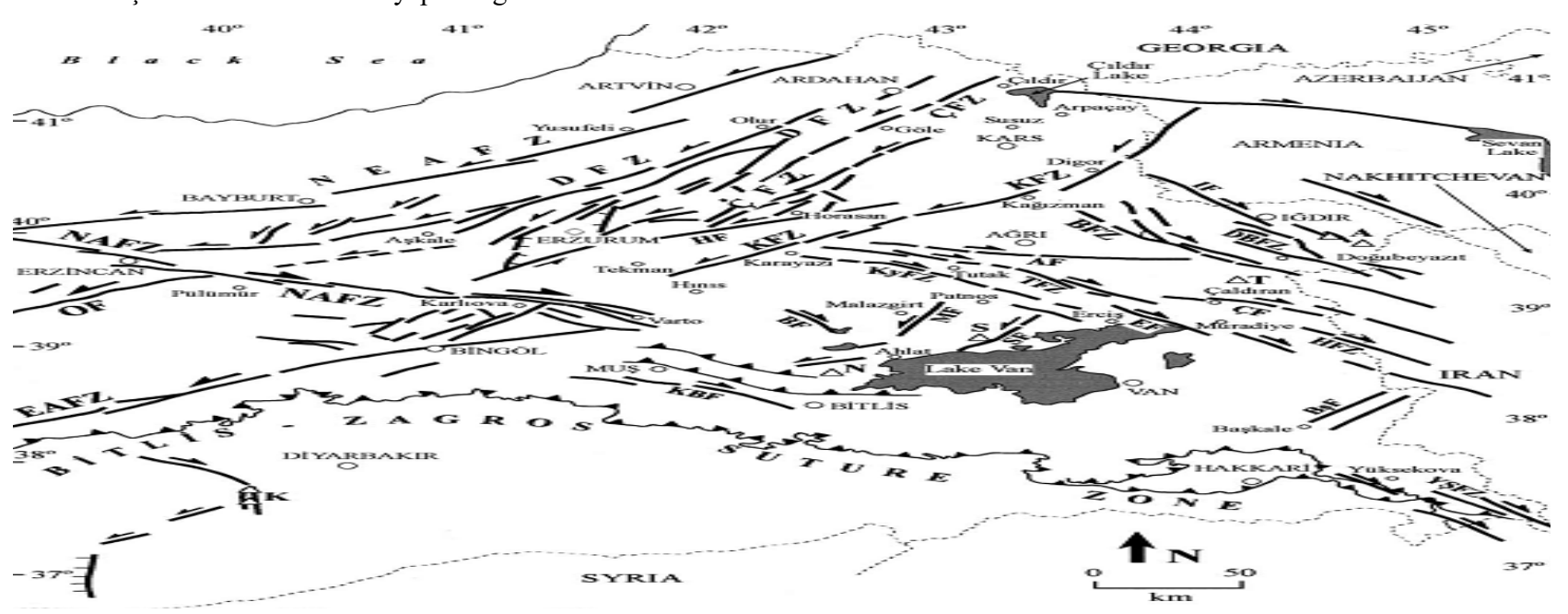

Kaynak: (Işıı vd., 2012)

Ek-3: Muş Vilayetinin Deprem Haritas1.

Kaynak: (Işık vd., 2012)
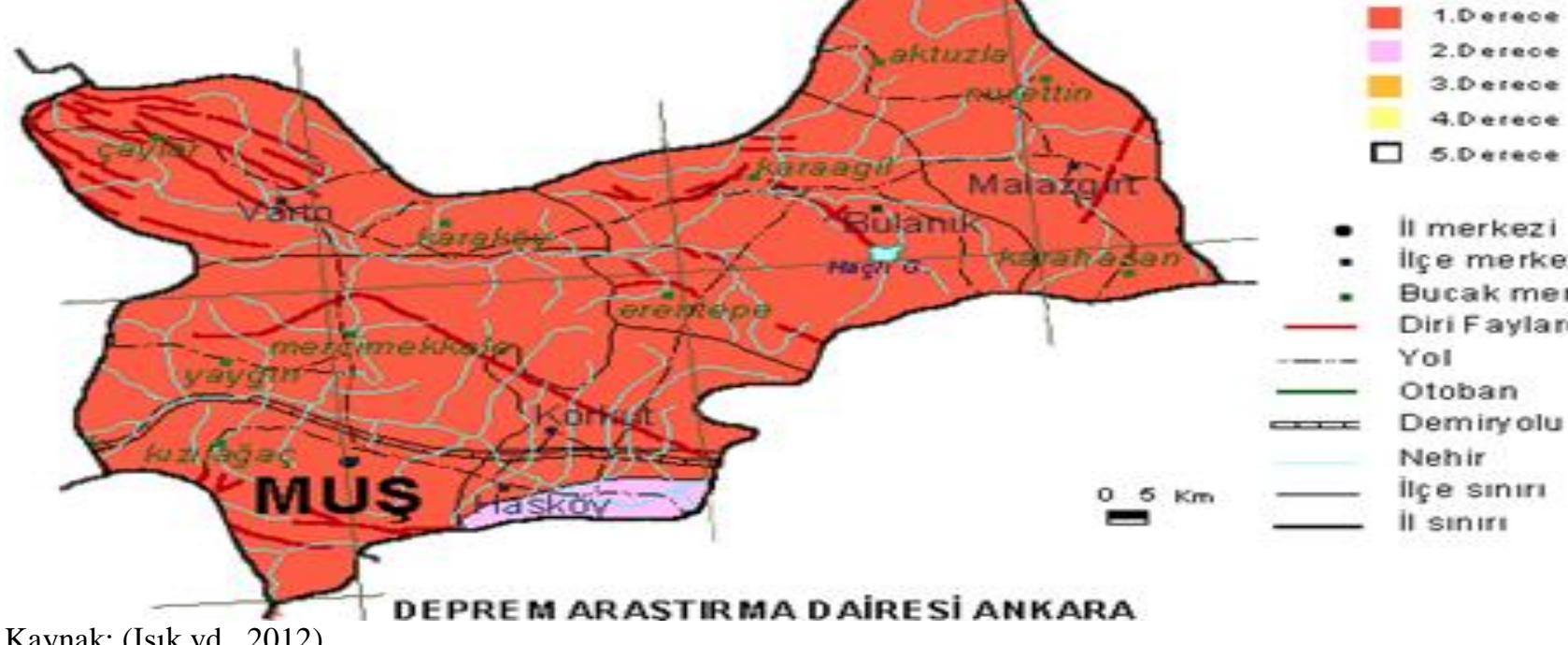

it merkezi

- itçe merkezi

- Bucak merkezi Diri Faylar(MTA) Yol

Otoban Demiryolu Nehir ilçe sınır il sinir! 
Ek-4: Malazgirt Depremindeki İnsan Kayıpları ve Bina Hasarlarını Gösteren Tablo.

\begin{tabular}{|c|c|c|c|c|c|c|c|c|c|c|c|c|c|c|}
\hline \multirow{2}{*}{ No- } & \multirow{2}{*}{$\begin{array}{c}\text { Tarih } \\
\text { gg/aa/yy }\end{array}$} & \multirow{2}{*}{$\begin{array}{c}\text { Lokasyon } \\
\text { Ülke } \\
\text { (Şehir/Kasaba) }\end{array}$} & \multicolumn{2}{|c|}{ Mercalli } & \multicolumn{3}{|c|}{ Derinlik $(\mathrm{km})$} & \multicolumn{5}{|c|}{ Can Kayb1 } & \multicolumn{2}{|c|}{ Hasarlı Binalar } \\
\hline & & & AFAD & KOERİ & AFAD & IISEE & TJES & AFAD & KOERİ & USGS & IISEE & WIKI & $\mathrm{AFAD}^{* *}$ & KOERİ \\
\hline 1 & $16-05-1900$ & Eskişehir & VI & - & - & - & - & - & - & - & - & - & 1 & - \\
\hline 2 & $12-07-1900$ & Kağızman/Kars & VIII & - & - & - & - & 140 & - & - & 140 & - & 2000 & - \\
\hline 3 & $19-12-1900$ & Doğubayazıt/Ağrı & VII & - & - & - & - & - & - & - & - & - & 55 & - \\
\hline 4 & 08-11-1901 & Pasinler (Erzurum) & VIII & - & - & - & - & - & - & - & - & - & 2000 & - \\
\hline 5 & $18-12-1901$ & Ayvalık (Balıkesir) & VIII & - & - & - & - & - & - & - & - & - & 104 & - \\
\hline 6 & 09-03-1902 & Çankırı & IX & - & - & - & - & 4 & - & - & 4 & - & 3000 & - \\
\hline 7 & 28-04-1903 & Malazgirt (Muş) & IX & - & - & - & - & 2803 & - & 3500 & 3560 & - & 12000 & - \\
\hline 8 & 29-04-1903 & Malazgirt (Muş) & - & IX & - & - & - & - & 600 & - & - & 600 & - & 450 \\
\hline 9 & $28-05-1903$ & Göle (Ardahan) & VIII & - & - & 16 & - & 1000 & - & 1000 & 1000 & - & 8000 & - \\
\hline 10 & 06-08-1903 & Bulanık (Muş) & VIII & - & - & - & - & 54 & - & - & - & - & - & - \\
\hline 11 & 04-12-1905 & Pütürge (Malatya) & IX & - & 30 & - & - & - & - & - & - & - & 15 & - \\
\hline 12 & 19-01-1909 & Foça (İzmir) & IX & - & - & - & - & 8 & $*$ & $*$ & 8 & $*$ & 1700 & $*$ \\
\hline 13 & 09-02-1909 & Sivas & VII & - & -- & - & - & - & - & - & - & - & 5000 & - \\
\hline 14 & 05-03-1909 & Yedisu (Bingöl) & VIII & - & - & - & - & - & - & - & - & - & 62 & - \\
\hline 15 & 29-10-1909 & $\begin{array}{c}\text { Karamürsel } \\
\text { (Kocaeli) }\end{array}$ & VII & - & - & - & - & - & - & - & - & - & 13 & - \\
\hline 16 & $18-08-1910$ & Palu (Elazığ) & VIII & - & - & - & - & 1 & - & - & - & - & 1600 & - \\
\hline 17 & 30-03-1912 & Şemdinli (Hakkâri) & VIII & - & - & - & - & 8 & - & - & - & - & 6 & - \\
\hline 18 & 09-08-1912 & Şarköy (Tekirdağ) & $X$ & - & 16 & - & - & 2836 & - & - & 2836 & - & 45169 & - \\
\hline
\end{tabular}

Kaynak: (Bikçe, 2016) 